\title{
Akses dan Pembagian Manfaat di dalam Draft Akademik Rancangan Undang-Undang Pengelolaan Sumber Daya Genetika
}

\section{Yulia ${ }^{1}$}

Dosen Fakultas Hukum Universitas Malikussaleh

Ketua Bagian Hukum Perdata Fakultas Hukum Universitas Malikussaleh

liahumaira_af@yahoo.com

\begin{abstract}
Access and benefits sharing is one principle in Convention on Biological Diversity (CBD) and reaffirmed in Nagoya Protocol. The principle has supported to provider countries of biodiversity to getting benefits sharing of used biodiversity by industries. Therefore, its to getting benefits sharing which fair and balanced, provider countries require specific regulation. Draf Akademik Rancangan Undang-undang Pengelolaan Sumber Daya Genetika (Academic Draft of RUU) is realization require of Indonesia to getting benefits sharing. This artikel has founds are Academic Draft of RUU the Genetic Resources Management has corresponding with CBD and Nagoya Protocol. Although, there are any points is not clear, as like scope of biodiversity and usage it.
\end{abstract}

Keywords:

Access and benefits sharing, biodiversity, CBD, Nagoya Protocol, Academic Draft RUU

\begin{abstract}
Abstrak
Akses dan pembagian manfaat merupakan satu prinsip yang telah disepakati di dalam Konvensi Keanekaragaman Hayati (KKH) dan ditegaskan kembali dalam Protokol Nagoya. Prinsip tersebut telah mendukung negara-negara penyedia keanekaragaman hayati dalam mendapatkan manfaat yang adil dan seimbang dalam penggunaan keanekaragaman hayati oleh industri-industri. Oleh karena itu, untuk mendapatkan pembagian manfaat yang adil dan seimbang maka negara-negara penyedia keanekaragaman hayati memerlukan peraturan yang khusus. Draf Akademik Rancangan Undang-undang Pengelolaan Sumber Daya Genetika adalah wujud dari keperluan Indonesia dalam menerapkan akses dan pembagian manfaat. Artikel ini telah mendapati bahwa Draf Akademik RUU Pengelolaan Sumber Daya Genetika telah menerapkan prinsip akses dan pembagian manfaaat sesuai dengan KKH dan Protokol Nagoya, meskipun ada beberapa hal yang belum jelas seperti ruang lingkup keanekaragaman hayati dan penggunaannya.
\end{abstract}

\section{Kata Kunci:}

Akses dan pembagian manfaat, keanekaragaman hayati, KKH, Protokol Nagoya, Draf Akademik RUU 


\section{A. PENDAHUluan}

\section{Draf Akademik Rancangan}

Undang-Undang Pengelolaan Sumber

Daya Genetika Tahun 2012 (Draf

Akademik RUU) adalah satu kemajuan

dalam mewujudkan penerapan

Konvensi Keanekaragaman Hayati

(KKH) dan Protokol Nagoya yang telah

diratifikasi. ${ }^{1}$ Salah satu prinsip yang

disepakati di dalam KKH adalah akses

dan pembagian manfaat. ${ }^{2}$ Prinsip ini

memberikan kesempatan bagi negara

penyedia keanekaragaman hayati

untuk mendapatkan manfaat dari

pemanfaatan keanekaragaman hayati

oleh negara pengguna. Meskipun

dalam $\mathrm{KKH}$, prinsip tersebut masih

bersifat himbauan dan belum

mengikat negara. ${ }^{3}$ Oleh karena itu,

${ }^{1} \mathrm{KKH}$ telah diratifikasi dengan Undang-undang Nomor 5 Tahun 1994 dan Protokol Nagoya dengan Undang-undang Nomor 11 Tahun 2013.

${ }^{2}$ M. Tvedt \& T. Young, 'Beyond Access: Exploring Implementation of the Fair and Equitable Sharing Commitment in the CBD', (2007) 67(2) IUCN-Environmental Policy and Law Paper; K. Venkataraman, 'Access and benefit sharing and the Biological Diveristy Act of India: a progress report', (2008) 10(3), Asian Biotechnology and Development Review, 69-80.

3 M. I. Jeffery, 'Bioprospecting: access to genetic resources and benefit sharing under the CBD and the Bonn Guidelines', (2002) 6, Singapore Journal International and Comparative Law, 747-808; C. Oguamanam, 'Genetic resources \& access and benefit sharing: politics, prospects and setiap negara penyedia keanekaragaman hayati perlu membuat perundang-undangan yang khusus dalam melindungi keanekaragaman hayati. ${ }^{4}$

Selanjutnya, di dalam Protokol Nagoya juga menegaskan kembali penerapan prinsip akses dan pembagian manfaat yang adil dan seimbang antara negara penyedia dengan negara pengguna keanekaragaman hayati. Protokol Nagoya menjadi peraturan yang mendukung untuk pelaksanaan prinsip akses dan pembagian manfaat dan Protokol ini telah merinci bagaimana setiap negara penyedia akan mendapat manfaat dalam penggunaan keanekaragaman hayati. ${ }^{5}$

opportunities for canada after nagoya', (2011) 22(2), Journal of Environmental Law and Practice, 87-201.

${ }^{4}$ J. Rana, Benefit Sharing of genetic resources convention on biodivesity, the bonn guidelines and emerging ABS framework, briefing paper 1, Research project on protection of indeginous knowledge of biodiversity, 2004; $\mathrm{K}$. Jung $\mathrm{Ni}$, 'The incorporation of the CBD mandate on access and benefit sharing into trips regime: an appraisal of the appeal of developing countries with rich genetic resource', (2006) 1, Asian J. WTO \& Int'l Health L \& Pol'y, 433- 464;

${ }^{5} \mathrm{~J}$. H. Vogel, et al, 'The Economics of Information, Studiously Ignored In The Nagoya Protocol On Access To Genetic 
Oleh karena itu, artikel ini akan menganalisa akses dan pembagian mafaat di dalam Draf Akademik Rancangan Undang-Undang Pengelolaan Sumber Daya Genetik Tahun 2012 dengan merujuk pada akses dan pembagian manfaat di dalam KKH dan Protokol Nagoya.

\section{B. PEMBAHASAN}

1. Latar Belakang Draf Akademik Rancangan Undang-undang Pengelolaan Sumber Daya Genetika Tahun 2012 (Draf Akademik RUU)

Perumusan Draf Akademik Rancangan Undang-Undang (Draf Akademik RUU) Pengelolaan Sumber Daya Genetika 2012 telah dijalankan pada tahun 2000 yang dinamai dengan Draf Akademik Rancangan Undang Undang Pelestarian dan Pemanfaatan Sumber Daya Genetika. Draf tersebut diketuai oleh Kementerian Pertanian dan telah menghasilkan Draf Akademik RUU Pelestarian dan Pemanfaatan Sumber Daya Genetika 2003 dan RUU Pelestarian dan Pemanfaatan Sumber Daya Genetika 2003. Namun semasa itu, Draf Akademik RUU Pelestarian dan

Resources and Benefit Sharing', (2011) 7, Law Env't \& Dev. J., 52-65

${ }^{6}$ Kementerian Hukum dan Hak Azasi Manusia,
Pemanfaatan Sumber Daya Genetika 2003 belum dimasukkan dalam Program Legislasi Nasional.

Kemudian pada tahun 2006, kewenangan perumusan Draf Akademik RUU Pelestarian dan Pemanfaatan Sumber Daya Genetika 2003 diserahkan ke Kementerian Lingkungan Hidup. Hal ini berdasarkan penilaian bahwa sumber daya genetika tidak saja berada di sektor pertanian. Kementerian Lingkungan Hidup merumuskan kembali Draf Akademik RUU Pelestarian dan Pemanfaatan Sumber Daya Genetika 2003, karena masih banyak isu-isu yang belum dimasukkan dalam Draf Akademik RUU Pelestarian dan Pemanfaatan Sumber Daya Genetika 2003. Perubahanpun telah dibuat bagi menyesuaikan dengan perkembangan terkini di dalam Conference of Parties (COP) termasuk isu akses dan pembagian manfaat. Draf Akademik RUU Pelestarian dan Pemanfaatan Sumber Daya Genetika pun dimasukkan dalam Program Legislasi Nasional 2010-2014.6 Oleh itu, Draf

http://ditjenpp.kemenkumham.go.id/prol egnas-2010-2014.html (2 April 2012); Lulu Agustina, Tim Penyusunan Draf Akademik Rancangan Undang-undang Pengelolaan Sumber Daya Genetika, 
Akademik RUU Pelestarian dan Pemanfaatan Sumber Daya Genetika 2003 telah mendapat kemajuan dalam proses perumusan dan lebih konprehensif berkaitan isu akses dan pembagian manfaat.

Lebih lanjut, Draf Akademik RUU Pelestarian dan Pemanfaatan Sumber Daya Genetika 2003 berubah menjadi menjadi Draf Akademik RUU Pengelolaan Sumber Daya Genetika. Ini dilakukan setelah melalui pembahasan panjang dengan institusiinstitusi yang terkait, yaitu Kementerian Lingkungan Hidup, Kementerian Pertanian, Kementerian Kelautan dan Perikanan, Kementerian Kesehatan, Balai Kliring Keanekaragaman Hayati, Lembaga Ilmu Pengetahuan Indonesia, Lembaga Swadaya Masyarakat, Institusi Akademik, wakil masyarakat dari berbagai daerah dalam beberapa kali pertemuan nasional. ${ }^{7}$ Perubahan nama "Pelestarian dan Pemanfaatan" menjadi "Pengelolaan" karena perlindungan, pelestarian, pemeliharaan dan penggunaan sumber daya genetika di dalam peraturan yang sama. Manakala nama 'Pelestarian dan

Kementerian Lingkungan Hidup, Jakarta, wawancara 12 Desember 2012.
Pemanfaatan' hanya merujuk kepada penggunaan saja. Oleh karena itu, perubahan Draf Akademik RUU Pengelolaan Sumber Daya Genetika 2012 tidak saja bertujuan untuk mengontrol "penggunaan", namun juga termasuk "perlindungan dan konservasi".

\section{Tujuan dan Ruang Lingkup Perumusan}

Tujuan Draf Akademik RUU Pengelolaan Sumber Daya Genetika 2012 adalah pengendalian sumber daya genetika melalui penggunaan secara berkesinambungan, pembagian mafaat dan menguatkan kemampuan dan pembangunan ilmiah, teknik serta teknologi di dalam negara. Pengendalian sumber daya genetika ialah pengawetan dan penggunaan sumber daya genetika. Pengawetan sumber daya genetika adalah rangkaian usaha untuk mempertahankan keberadaan dan berbagai sumber daya genetika dalam keadaan dan potensial yang mendukung untuk penggunaan secara berkesinambungan melalui konservasi. Hal ini merujuk pada pengawetan sumber daya genetika in situ dan ex situ di wilayah Indonesia, di darat, di laut, air

7 Lulu Agustina, wawancara 12 Desember 2012. 
tawar yang dimiliki oleh negara atau perseorangan. ${ }^{8}$

Ruang lingkup Draf Akademik RUU Pengelolaan Sumber Daya Genetika 2012, yaitu: (i) sumber daya genetika, derivatif dan kearifan berkaitan dengan sumber daya genetika; (ii) status kawasan kewujudan sumber daya genetika; (iii) status kepemilikan sumber daya genetika; (iv) pengontrolan sumber daya genetika in situ dan ex situ; (v) sifat derivatif sumber daya genetika; (vi) sifat inovasi dan kearifan lokal; (vii) mengontrol prosedur akses, syarat pengungkapan informasi awal dan persetujuan bersama; (viii) mengontrol pembagian manfaat; (ix) kewenangan institusi nasional; serta (x) pemantauan dan pengesahan undang-undang. 9 Jadi, ruang lingkup Draf Akademik RUU Pengelolaan Sumber Daya Genetika 2012 telah menerangkan sumber daya genetika termasuk derivatif dan kearifan lokal.

Sumber daya genetika ialah semua material genetika dan informasi genetika dari tumbuhan,

\footnotetext{
8 Pengawetan sumber daya genetika in situ dilaksana pada tempat asalnya dengan menjaga kesinambungannya. Manakala pengawetan ex situ dilaksanakan di luar tempat asal sebagai mendukung pelestarian in situ dengan mengumpulkan
}

hewan, mikroba atau derivatif termasuk derivatif yang mengandung unit fungsi pewarisan sifat yang mempunyai nilai nyata atau potensial. "Definisi derivatif ialah molekul atau kombinasi atau campuran dari molekul-molekul alam, termasuk material aktif mentah dan organisme hidup atau yang diperoleh dari hasil metabolisme hidup. Definisi ini hampir sama dengan definisi di dalam $\mathrm{KKH}$, namun penggunaan istilah mencakup "derivatif" sebagaimana didefinisikan di dalam artikel 2(e) Protokol Nagoya.

Kearifan lokal berkaitan dengan sumber daya genetika di dalam Draf Akademik RUU Pengelolaan Sumber Daya Genetik 2012, terdapat 6 kriteria, yaitu: pertama, pengetahuan, keterampilan, inovasi dan praktek masyarakat lokal berkait; kedua, berbentuk lisan, tulisan dan bentuk-bentuk lain; ketiga, diturunkan dari generasi ke generasi; keempat, berasal dari tradisi kultur; kelima, diatur dalam undang-undang adat; keenam, kepemilikan bersifat kolektif; dan ketujuh, kearifan lokal bergantung

komponen-komponen keanekaragaman hayati.

9 Draf Akademik Rancangan UndangUndang Pengelolaan Sumber Daya Genetika 2012, hlm 62. 
kepada sumber daya alam dan tidak bergantung dengan sumber keuangan. Karena keberkaitan tersebut, akses kepada kearifan lokal masyarakat perlu dikontrol bersamaan dengan sumber daya genetika. Oleh itu, Draf Akademik RUU Pengelolaan Sumber Daya Genetika 2012 telah mengakui keberkaitan kearifan lokal dengan sumber daya genetika seperti yang ditegaskan dalam artikel 8(j) KKH dan artikel 7 Protokol Nagoya. Jadi, tujuan dan ruang lingkup perumusan di dalam Draf Akademik RUU Pengelolaan Sumber Daya Genetika 2012 adalah meluas meliputi akses kepada sumber daya genetika termasuk derivatif dan turunannya seperti mana diterangkan di dalam Protokol Nagoya.

\section{Akses kepada sumber daya genetika}

Isu akses kepada sumber daya genetika di dalam Draf Akademik RUU Pengelolaan Sumber Daya Genetika 2012, menerangkan bahwa kegiatan untuk memperoleh atau menggunakan sumber daya genetika dalam kondisi in

\footnotetext{
${ }^{10}$ Miranda Risang Ayu, Tim Penyusun Draf Akademik Rancangan UndangUndang Pengelolaan Sumber Daya Genetika, Jakarta, wawancara 6 November 2013.
}

situ, ex situ termasuk derivatif dan produk derivatif serta pengetahuan yang melekat untuk penelitian dan pembangunan, pengumpul, tukar menukar, bioprospek, pengawetan dan tujuan lain. 10 Oleh karena itu, perkataan "memperoleh" atau "menggunakan" bermakna "kegiatan hanya untuk memperoleh sumber daya genetika saja" tanpa menggunakan sendiri atau hanya menggunakan saja tanpa diperoleh secara pengambilan sendiri.

Akses kepada sumber daya genetika dapat dilaksanakan melalui kegiatan penelitian, pembangunan sumber daya genetika atau derivatif secara berkesinambungan melalui pemakaian teknologi. ${ }^{11}$ Negara penyedia tidak mempunyai teknologi, kegiatan penelitian, pembangunan dalam akses kepada sumber daya genetika diperlukan kerjasama antara penyedia dengan pengguna sebagaimana ditegaskan di dalam KKH dan Protokol Nagoya. ${ }^{12}$

\footnotetext{
11 Draf Akademik Rancangan UndangUndang Pengelolaan Sumber Daya Genetika 2012, hlm 67.

12 Artikel 15, 16, 18 dan 19 KKH. Ia juga dilaksanakan di dalam artikel 23 Protokol Nagoya.
} 
Akses kepada sumber daya genetika di dalam Draf Akademik RUU Pengelolaan Sumber Daya Genetika 2012 dapat dilaksanakan untuk tujuan komersil dan bukan komersil.13 Draf Akademik RUU Pengelolaan Sumber Daya Genetika 2012 telah menyetujui 2 (dua) cara memperoleh akses kepada sumber daya genetika.

Akses kepada sumber daya genetika di bawah kewenangan negara dapat dilakukan oleh setiap warga negara untuk tujuan penelitian dan perkembangan ilmiah, teknologi serta peningkatan manfaat sumber daya genetika. Draf Akademik RUU Pengelolaan Sumber Daya Genetika 2012, tidak secara jelas menyebutkan pengguna bukan warga negara. ${ }^{14}$ Jadi, Draf Akademik RUU Pengelolaan Sumber Daya Genetika 2012 masih perlu menerangkan secara tegas isu pengguna. Karena, berkaitan dengan akses yang dapat dijalankan dibedakan untuk kepentingan penelitian akademik, adakah diperlukan memperoleh peng-

13 Pengaturan ini tidak secara terang di dalam KKH dan Protokol Nagoya, namun ia adalah tersirat di dalam artikel 15(1) KKH dan artikel 6(1) Protokol Nagoya.

14 Miranda Risang Ayu, wawancara 6 November 2013; Walaupun KKH dan Protokol Nagoya tidak menyebutkan ungkapan informasi awal dan perjanjian pembagian manfaat. Perkara ini penting bagi mencegah terjadinya pencurian hasil penelitian oleh pengguna yang tidak perlu membuat perjanjian pembagian manfaat.

Prosedur akses kepada sumber daya genetika dilaksanakan dengan membuat permohonan akses kepada Otoritas Nasional. Otoritas Nasional memberikan kewenangan kepada Institusi Sektoral jika permohonan telah diketahui nilai potensial. Pemohon akses perlu mendapat pengungkapan informasi awal dari masyarakat atau pemilik sumber daya genetika. Otoritas Nasional dan Institusi Sektoral akan mengkaji permohonan akses dengan nasehat dan persetujuan dari Tim Teknikal. Otoritas Nasional dan Institusi Sektoral dapat memberi persetujuan atau menolak permohonan akses.15 Namun, di dalam Draf Akademik RUU Pengelolaan Sumber Daya Genetika 2012, prosedur

secara jelas kategori pengguna yang dapat melakukan akses, negara dapat memperincikannya berdasarkan artikel 15(1) KKH dan 6(1) Protokol Nagoya.

15 Draf Akademik Rancangan UndangUndang Pengelolaan Sumber Daya Genetika 2012, hlm. 68. 
akses belum diterangkan berapa lama izin akses boleh didapat. Oleh itu, prosedur akses di dalam Draf Akademik RUU Pengelolaan Sumber Daya Genetika 2012 perlu diatur melalui peraturan pelaksana.

Isu pengelolaan sumber daya genetika di dalam kewenangan "satu pintu" (one stop centre) dalam mengelola sumber daya genetika, ${ }^{16}$ dalam komposisi, yaitu: Otoritas Nasional, Tim Teknikal, Balai Kliring Akses dan Pembagian Manfaat dan Pos Pemeriksaan. Mereka adalah komposisi yang akan mengelola sumber daya genetika dalam pemberian izin akses, pengaturan izin akses dan konservasi sumber daya genetika. Kewenangan bagi institusi "satu pintu" (one stop centre), yaitu: bagi menerima dan menilai permohonan akses dan kelengkapan prosedur serta perpanjangan izin; memberikan izin akses kepada sumber daya genetika; memantau dan menilai

\footnotetext{
${ }^{16}$ Draf Akademik Rancangan UndangUndang Pengelolaan Sumber Daya Genetik 2012, hlm 77, menerangkan pengawalselia akses ke atas keanekaragaman hayati dan sumber genetik melalui "kelembagaan satu pintu"; Miranda Risang Ayu, 6 November 2013.

$$
\begin{aligned}
& { }^{17} \text { Idem. } \\
& { }^{18} \text { Idem. }
\end{aligned}
$$
}

izin akses bersama dengan kementerian yang berkaitan; serta membatalkan dan manarik balik izin akses yang melanggar prosedur atau ketentuan perjanjian akses. ${ }^{17}$ Oleh itu, Draf Akademik RUU Pengelolaan Sumber Daya Genetika 2012 telah menguraikan komposisi dari institusi yang ditegaskan di dalam "satu pintu".

Otoritas Nasional adalah satu dari komposisi institusi "satu pintu", yang mempunyai tugas menerbitkan izin akses. Hal ini mestilah bebas; berkemampuan dalam mengkaji permohonan izin; transparan; tetap; mempunyai kewenangan yang diturunkan oleh undang-undang; dan mempunyai kemampuan untuk mewakili pihak-pihak berkepentingan. ${ }^{18}$ Otoritas Nasional mempunyai kewenangan untuk menerima atau menolak permohonan izin akses. Manakala kewenangan juga diberikan pada Institusi Sektoral bagi mengkaji permohonan akses. ${ }^{19}$ Oleh

19 Di antara Otoritas Nasional dan Institusi Sektoral berlaku konflik kepentingan dalam memberi izin akses. Ia adalah karena selama ini pengelolaan sumber daya genetika diuruskan oleh beberapa institusi sektoral. Ketika Draf akademik RUU Pengelolaan Sumber Daya Genetika memberikan kuasa pemberian izin akses pada Otoritas Nasional, ia mempupuskan kuasa pada Institusi Sektoral. Giorgio Budi Indarto, 
karena itu, hal tersebut dapat mempengaruhi pada pengurusan izin akses, yaitu menghabiskan masa yang lama karena permohonan izin akses diajukan ke Otoritas Nasional. Manakala permohonan akses mempunyai nilai potensial akan diberikan kewenangan ke Institusi Sektoral untuk mengkaji permohonan akses dan menjadi kesukaran dalam mengawal izin akses kepada sumber daya genetika.

Pemberian kewenangan memberi izin oleh Institusi Sektoral adalah "mendelegasi" kewenangan dari Otoritas Nasional. Makna "mendelegasi" di dalam undangundang, dibedakan dalam dua makna, yaitu: pertama, pelimpahan kewenangan termasuklah tanggung jawab dan kontrol; dan kedua, penyerahan kewenangan atau mewakilkan tanpa penyerahan tanggung jawab dan kontrol. Menurut Miranda Risang Ayu, makna "mendelegasikan" bukanlah

Kelembagaan dalam pengelolaan sumber daya genetik di Indonesia, makalah, Workshop Nasional Akses terhadap Sumber Daya Genetika dan pembagian keuntungan atas pemanfaatanya, kerjasama Kementerian Negara Lingkungan Hidup, Departemen Pertanian, Departemen Luar Negeri dan Yayasan Kehati, Jakarta, Agustus 2007. "pelimpahan" kewenangan kepada Institusi Sektoral, karena ia hanya merujuk kepada kewenangan pelaksanaan diberi kepada Institusi Sektoral. Tanggung jawab dan kontrol berada di bawah Otoritas Nasional. 20 Namun, hal demikian tetap berpengaruh kepada pelaksanaan dalam pemberian izin akses.

Oleh karena itu, Draf Akademik RUU Pengelolaan Sumber Daya Genetika 2012, kewenangan penerbitan izin masih melibatkan dua institusi. Ini adalah karena adanya permohonan yang dikaji oleh Institusi Sektoral bagi yang sudah diketahui nilai potesial dan ada yang dikaji melalui Otoritas Nasional bagi yang belum diketahui nilai potensial. Perkara ini akan mengambil masa yang lama karena harus dikaji dahulu oleh Otoritas Nasional mengenai perwujudan nilai potensial atau tidak potensial. Ia juga dapat mempengaruhi kepada biaya akses yang perlu

${ }^{20}$ Miranda Risang Ayu, wawancara 6 November 2013; S. F. Marbun \& M. Mahfud M.D, Pokok-Pokok Hukum Administrasi Negara, Liberty, Yogyakarta, 2006; P. Atmosudirdjo, Hukum Administrasi Negara, Ghalia Indonesia, Jakarta, 1981; P. M. Hadjon, Pengantar Hukum Administrasi Indonesia, Gadjah Mada University Press, Yogyakarta, 2005. 
dikeluarkan oleh pengguna sumber daya genetika.

Isu pengungkapan informasi awal di dalam Draf Akademik RUU Pengelolaan Sumber Daya Genetika 2012, menerangkan bahwa izin akses kepada sumber daya genetika diberikan setelah mendapat pengungkapan informasi awal daripada masyarakat atau pemilik sumber daya genetika. Syarat pengungkapan informasi awal dalam akses kepada sumber daya genetika mestilah mempunyai kepastian undang-undang, perlu memudahkan akses kepada sumber daya genetika dengan biaya yang rendah, membatasi akses kepada sumber daya genetika perlu transparan dan tidak bertentangan dengan tujuan konservasi, persetujuan dari Otoritas Nasional atau pemegang kepentingan seperti masyarakat atau kumpulan masyarakat. ${ }^{21}$ Pengaturan ini adalah menepati sebagaimana pengaturan di dalam artikel 15(5) KKH dan artikel 6(3) Protokol Nagoya. Oleh itu, bahwa Draf Akademik RUU Pengelolaan Sumber Daya Genetika 2012 menerangkan pengungkapan infor-

21 Draf Akademik Rancangan UndangUndang Pengelolaan Sumber Daya Genetika 2012, hlm 68. masi awal mesti diberikan menurut kaedah praktis di dalam masyarakat asal. Persetujuan pengungkapan informasi awal diberikan berasaskan kepada tujuan akses, ruang lingkup akses dan jangka waktu. Hal ini menepati dengan pengaturan di dalam artikel 6(1) dan artikel 12(1) Protokol Nagoya. Draf Akademik RUU Pengelolaan Sumber Daya Genetika 2012 juga menerangkan persetujuan peng-ungkapan informasi awal dalam akses yang dilakukan dengan melibatkan masyarakat asal.

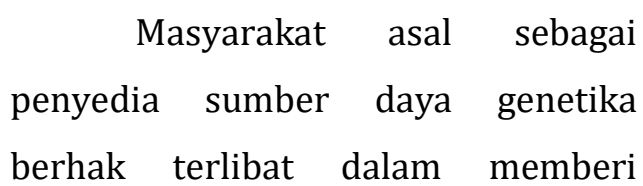
persetujuan pengungkapan informasi awal. KKH belum menerangkan penglibatan masyarakat asal berhak terlibat dalam pengungkapan informasi awal dalam akses sumber daya genetika dan kearifan lokal di dalam artikel 8(j) KKH dan seksyen 15 KKH. Namun telah ditegaskan di dalam pengaturan artikel 6(2) dan artikel 6(3)(f) Protokol Nagoya. Oleh itu, masyarakat asal patutlah menjadi pihak yang berkuasa dalam memberi pengungkapan informasi awal. 
Namun, Draf Akademik RUU Pengelolaan Sumber Daya Genetika 2012 belum menerangkan secara terperinci persetujuan memperoleh pengungkapan informasi awal dari masyarakat asal.

Pengungkapan informasi awal melibatkan masyarakat, di mana masyarakat perlu: mendokumentasikan secara tertulis kearifan lokal yang dimiliki dan mendaftarkan sumber daya genetika di sekitar masyarakat; (ii) menjaga kelangsungan sumber daya genetika yang ada di sekitarnya; (iii) memelihara budaya, pengetahuan, inovasi dan pelaksanaan melalui pengawalan sumber daya genetika secara berkesinambungan; (iv) memantau pelaksanaan akses kepada sumber daya genetika yang berada di sekitarnya. ${ }^{22}$ Oleh itu, keperluan ini dapat mendukung masyarakat dalam melindungi hak-haknya kepada sumber daya genetika sebagaimana ditegaskan dalam pengaturan di dalam artikel 6(2) Protokol Nagoya.

Oleh karena itu, bahwa kewenangan pengelolaan sumber

22 Draf Akademik Rancangan UndangUndang Pengelolaan Sumber Daya Genetika 2012, hlm 75. daya genetika serta pengungkapan informasi awal di dalam Draf Akademik RUU Pengelolaan Sumber Daya Genetika 2012 masih belum terperinci. Kewenangan yang mengkaji dan menerbitkan izin masih merujuk kepada dua institusi yang berbeda berasaskan nilai potensial dan tidak potensial permohonan akses. Sebab itu dapat melibatkan masa yang lama melalui pengkajian oleh Otoritas Nasional, jika diketahui mempunyai nilai potensial diturunkan kepada Institusi Sektoral.

\section{Perkongsian Faedah melalui Draf Akademik Rancangan Undang-undang Pengelolaan Sumber Daya Genetika 2012}

Isu kepemilikan sumber daya genetika di dalam Draf Akademik RUU Pengelolaan Sumber Daya Genetika 2012, menerangkan pemilik sumber daya genetika dikategorikan dalam 3 kategori, yaitu negara, masyarakat dan kumpulan masyarakat. Kepemilikan negara kepada sumber daya genetika adalah menepati keperluan berkaitan pengaturan hak kedaulatan negara kepada sumber daya genetika di dalam Pasal 33 Undang-Undang Dasar 1945, artikel 15 KKH dan artikel 6 Protokol 
Nagoya. Kepemilikan masyarakat dan kumpulan masyarakat kepada sumber daya genetika di wilayah mereka termasuk kearifan lokal berkaitan sumber daya genetika. Itu adalah menepati keperluan pengaturan di dalam artikel 8(j) KKH.

Menurut Miranda Risang Ayu, bagaimanapun, sukar untuk menentukan pemilik yang sah untuk sumber daya genetika dan kearifan lokal. Ini adalah karena struktur masyarakat di Indonesia yang terdiri dari pelbagai suku di beberapa daerah yang mempunyai sumber daya genetika dan kearifan lokal yang hampir sama. Disarankan agar negara boleh menangani kepemilikan yang tidak diketahui pemilik yang sah. Negara juga boleh menjadi pihak dalam perjanjian pembagian manfaat. ${ }^{23}$ Oleh itu, bahwa kepemilikan sumber daya genetika di dalam Draf Akademik RUU Pengelolaan Sumber Daya Genetika 2012 melibatkan kepada masyarakat asal sebagai pemilik kearifan lokal berkaitan keanekaragaman hayati. Manakala bagi sumber daya genetika

23 Miranda Risang Ayu, wawancara 6 November 2013. yang tidak diketahui pemilik yang sah adalah milik negara.

\section{Pembagian Manfaat dan Perjanjian Pembagian Manfaat}

Isu pembagian manfaat di dalam Draf Akademik RUU Pengelolaan Sumber Daya Genetika, telah menguraikan pembagian manfaat, yaitu:24 (i) perlu menjamin penggunaan sumber daya genetika secara berkesinambungan, sebagaimana yang ditegaskan di dalam artikel 9 Protokol Nagoya; (ii) Pembagian mengenai informasi atau kearifan lokal; (iii) Ganti rugi untuk penggunaan langsung; (iv) Akses kepada teknologi termasuk bioteknologi; dan (v) usaha pembangunan produk mempunyai aspek komersil dan aspek HKI. Oleh itu, Draf Akademik RUU Pengelolaan Sumber Daya Genetika 2012 telah menerangkan pembagian manfaat termasuk teknologi dan bioteknologi yang perlu dimasukkan di dalam perjanjian pembagian manfaat. Perkara ini penting bagi menjamin pembagian manfaat yang diperoleh dari penggunaan sumber daya

${ }^{24}$ Draf Akademik Rancangan UndangUndang Pengelolaan Sumber Daya Genetik 2012, hlm 64-65. 
genetika secara teknologi dan bioteknologi.

Isu perjanjian pembagian manfaat di dalam Draf Akademik RUU Pengelolaan Sumber Daya Genetika 2012, menguraikan bahwa setelah memperoleh persetujuan pengungkapan informasi awal daripada pemilik sumber daya genetika, pengguna mesti membuat perjanjian pembagian manfaat dengan masyarakat di mana sumber daya genetika dan kearifan lokal dipergunakan. Manakala sumber daya genetika adalah di bawah kewenangan negara maka perjanjian akses dan pembagian manfaat dibuat dengan Otoritas Nasional atau Institusi Sektoral.25 Oleh itu, Draf Akademik RUU Pengelolaan Sumber Daya Genetika 2012 telah menepati pengaturan keperluan perjanjian pembagian manfaat di dalam KKH dan Protokol Nagoya.

Perjanjian pembagian manfaat perlu dirundingkan tanpa melibatkan biaya yang besar. Ini penting bagi

25 Hal ini diasaskan kepada nilai potensial sumber daya genetika yang sudah diketahui diturunkan kuasa ke Institusi Sektoral dan sumber daya genetika yang belum diketahui dilaksanakan oleh Otoritas Nasional. memastikan adanya Perjanjian Pengalihan Material yang seragam dan berdasarkan kepada persamaan tujuan dan jenis sumber daya genetika yang digunakan dalam akses. Misalnya, untuk tujuan dan jenis sumber daya genetika yang sama maka mestilah menggunakan Perjanjian Pengalihan Material yang sama. ${ }^{26} \mathrm{KKH}$ tidak membuat terperinci bentuk perjanjian pembagian manfaat, bagaimanapun artikel 19 Protokol Nagoya menjelaskan model klausa kontrak untuk pembangunan dan penggunaan model kontrak sektoral serta lintas sektoral dalam persetujuan bersama.

Isu persetujuan bersama di dalam Draf Akademik RUU Pengelolaan Sumber Daya Genetika 2012, menerangkan bahwa, yaitu:27

(i) perlu dibuat dalam bentuk dokumen tertulis sebagai dasar perkongsian faedah antara penyedia dengan pengguna sumber daya genetika, ia adalah sama seperti di dalam artikel 6(3)(g) Protokol Nagoya;

\footnotetext{
${ }^{26}$ Draf Akademik Rancangan UndangUndang Pengelolaan Sumber Daya Genetika 2012, hlm 69.

27 Idem.
} 
(ii) perlanggaran perjanjian akses yang dibuat dapat dikenakan sanksi, sebagaimana pengaturan dalam undang-undang. Hal itu karena setiap persetujuan bersama mesti ditaati oleh pihak-pihak, sesuai dengan artikel 18(1) Protokol Nagoya; dan (iii) penggunaan sumber daya genetika termasuk informasi derivatif untuk penelitian dan komersil perlu berdasarkan persetujuan bersama, yang sama dengan pengaturan di dalam artikel 6(3)(g) Protokol Nagoya.

Oleh karena itu, persetujuan bersama di dalam Draf Akademik RUU Pengelolaan Sumber Daya Genetika 2012, telah menerangkan keadaankeadaan yang diperlukan dalam persetujuan bersama. Namun, Draf Akademik RUU Pengelolaan Sumber Daya Genetika 2012, belum menguraikan secara rinci bagaimana persetujuan bersama dalam sumber daya genetika di dalam kewenangan kearifan lokal. Ini dapat terperinci di dalam peraturan pelaksana bagi mendukung pembagian manfaat.

\section{Kontrol akses kepada sumber daya genetika dan Bentuk Manfaat}

Isu kontrol akses kepada sumber daya genetika di dalam Draf Akademik RUU Pengelolaan Sumber
Daya Genetika 2012, dilakukan oleh Pos Pemeriksaan (Check Point). Ia berfungsi untuk melakukan kontrol atas penggunaan sumber daya genetika. Ia akan mengumpulkan dan menerima informasi yang relavan berkaitan dengan pengungkapan informasi awal, sumber asal sumber daya genetika, pembuatan persetujuan bersama dan penggunaan sumber daya genetika. Ini adalah menepati pengaturan di dalam artikel 17(1)(a)(i) Protokol Nagoya. Manakala Pos pemeriksaan akan melaksanakan fungsi pengontrolan penggunaan sumber daya genetika di setiap tahap, misal, penelitian, pembangunan, penciptaan, sebelum komersil, proses pendaftaran HKI dan komersil adalah menepati keperluan di dalam artikel 17(1)(a)(iv) Protokol Nagoya.

Isu kontrol pelaksanaan izin akses di dalam Draf Akademik RUU Pengelolaan Sumber Daya Genetika 2012, bahwa dilaksanakan oleh setiap wakil dari institusi berkaitan di dalam Pos Pemeriksaan, yaitu: terdiri dari wakil-wakil daripada Otoritas Kewenangan Nasional, Insitusi Penelitian Pemerintah, Universitas, Cukai, Pengurus Karantina, Pengurus Kawasan Konservasi, Institusi 
Masyarakat dan Kantor HKI. Pengontrolan dijalankan dengan merujuk kepada: (i) Persetujuan pengungkapan informasi awal;28 (ii) Akses dan pembagian manfaat telah dilakukan dengan persetujuan bersama;29 dan (iii) Sertifikat izin akses yang diberikan oleh Otoritas Nasional mempunyai skop informasi antara penyedia dengan pengguna dan tujuan akses. Ketiga-tiganya adalah sebagai pedoman dalam menjalankan kontrol dalam pelaksanaan izin akses. Oleh itu, Draf Akademik RUU Pengelolaan Sumber Daya Genetika 2012, telah menguraikan kewenangan kontrol kepada izin akses dengan menggunakan cek list pengawalan.

Isu bentuk manfaat di dalam Draf Akademik RUU Pengelolaan Sumber Daya Genetika 2012, telah menerangkan bentuk manfaat dengan merujuk pada artikel 5(4) Protokol Nagoya dan Pedoman Bonn. Hal ini terdiri dari bentuk manfaat keuangan

\footnotetext{
${ }^{28}$ Sebagaimana di dalam artikel 15(5) KKH yaitu akses telah mendapat persetujuan keizinan berasaskan informasi awal berasaskan undangundang negara penyedia sebagaimana yang dinyatakan di dalam artikel 6(2) Protokol Nagoya.

${ }^{29}$ Sebagaimana di dalam artikel 15(4) KKH dan artikel 5(1) Protokol Nagoya.
}

dan manfaat bukan keuangan. Manfaat keuangan tidak terbatas pada: ${ }^{30}$

(a) pembiayaan akses per satu bagi setiap sampel yang dikumpulkan,

(b) pembayaran pendahuluan;

(c) pembayaran pada tahap penting;

(d) pembayaran royalti;

(e) pembiayaan izin bagi kegiatan komersil

(f) biaya khas untuk dana konservasi;

(g) gaji atau fee yang dipersetujui bersama;

(h) dana penelitian,

(i) usaha penggabungan modal;

(j) kepemilikan bersama HKI.

Manakala manfaat bukan

keuangan juga tidak terbatas kepada: ${ }^{31}$

(a) perkongsian hasil penyelidikan;

(b) kolaborasi, kerjasama dan sumbangan dalam programprogram penelitian ilmiah, khas kegiatan penelitian bioteknologi;

(c) partisipan dalam pembangunan produk;

(d) kolaborasi, kerjasama dan sumbangan dalam pendidikan dan pelatihan;

(e) izin masuk bagi kemudahan ex situ sumber daya genetika dan pangkalan data;

(f) pemindahan pengetahuan dan teknologi pada penyedia dengan persyaratan yang adil dan seimbang,

(g) memperkukuh kemudahan pemindahan alih teknologi;

(h) pembangunan kapasitas institusi;

${ }^{30}$ Draf Akademik Rancangan UndangUndang Pengelolaan Sumber Daya Genetik 2012, hlm 72 .

${ }^{31}$ Idem. 
(i) pembangunan sumber manusia untuk memperkuat kapasitas pelayanan;

(j) pelatihan berkaitan dengan sumber daya genetika;

(k) akses ke informasi ilmiah yang relavan;

(l) sumbangan kepada ekonomi lokal;

(m) penelitian ditujukan pada keutamaan keperluan, seperti kesehatan;

(n) hubungan institusi dan profesional;

(o) manfaat makanan dan keamanan pekerjaan;

(p) pengakuan sosial;

(q) kepemilikan bersama HKI yang relevan.

Oleh itu disimpulkan, bahwa ruang lingkup manfaat di dalam Draf Akademik RUU Pengelolaan Sumber Daya Genetika 2012, adalah amat meluas. Ini diterangkan melalui ketentuan 'tidak terbatas', maknanya manfaat di luar daripada list yang terdapat di dalam Draf Akademik RUU Pengelolaan Sumber Daya Genetika 2012 dapat dipersetujui bersama dalam perjanjian pembagian manfaat. Sebagai contoh, bentuk manfaat bukan keuangan, seperti pelatihan, pendidikan, pembangunan sarana lebih relevan dan dapat memberdayakan masyarakat.

Manakala isu HKI dan pemindahan hasil penelitian di dalam Draf Akademik RUU Pengelolaan Sumber Daya Genetika 2012, belum diuraikan. Keadaan ini diperlukan bagi penggunaan spesies tanaman Indonesia untuk mendapat hak di dalam HKI atau pemindahan hasil penelitian kepada pihak lain yang bertujuan komersil. Oleh itu, ketentuan HKI dan pemindahan hasil penelitian, dapat mendukung perlindungan sumber daya genetika dari kegiatan pencurian sumber daya genetika.

Oleh itu disimpulkan, di dalam Draf Akademik RUU Pengelolaan Sumber Daya Genetika 2012 terdapat isu yang tidak dibahas secara jelas. Oleh karena itu perlu merumuskan pasal-pasal RUU Pengelolaan Sumber Daya Genetika secara kukuh, mantap dan menepati keperluan akses dan pembagian manfaat di dalam KKH dan Protokol Nagoya.

\section{KESIMPULAN}

Akses dan pembagian manfaat kepada sumber daya genetika di dalam Draf Akademik RUU Pengelolaan Sumber Daya Genetika 2012 sudah sesuai dengan keperluan pengaturan berkaitan akses dan pembagian manfaat di dalam KKH dan Protokol Nagoya. Hal ini jelas terlihat dalam uraian pengguna-pengguna akses kepada sumber daya genetika, meskipun masih ada hal-hal yang 
belum jelas ditegaskan seperti ruang lingkup akses keanekaragaman hayati, pengguna akses, perlindungan $\mathrm{HKI}$, pemindahan hasil penelitian termasuk kearifan lokal yang tidak diketahui pemilik yang sah. Draf Akademik RUU Pengelolaan Sumber Daya Genetika 2012 juga telah menerangkan mesti membuat perjanjian pembagian manfaat melalui persetujuan bersama. Namun, ia belum menerangkan perjanjian pembagian manfaat untuk tujuan akademik dan komersil. Ia juga belum memastikan kepemilikan HKI dan pemindahan hasil penelitian dari penggunaan sumber daya genetika Indonesia.

\section{DAFTAR PUSTAKA}

C. Oguamanam, 'Genetic resources \& access and benefit sharing: politics, prospects and opportunities for canada after nagoya', (2011) 22(2), Journal of Environmental Law and Practice, 87-201.

Draf Akademik Rancangan UndangUndang Pengelolaan Sumber Daya Genetika 2012.

Kementerian Hukum dan Hak Azasi Manusia, http://ditjenpp.kemenkumham.go .id/prolegnas-2010-2014.html (2 April 2012).

Giorgio Budi Indarto, Kelembagaan dalam pengelolaan sumber daya genetik di Indonesia, makalah,
Workshop Nasional Akses terhadap Sumber Daya Genetika dan pembagian keuntungan atas pemanfaatanya, kerjasama Kementerian Negara Lingkungan Hidup, Departemen Pertanian, Departemen Luar Negeri dan Yayasan Kehati, Jakarta, Agustus 2007.

J. H. Vogel, et al, "The Economics of Information, Studiously Ignored In The Nagoya Protocol On Access To Genetic Resources and Benefit Sharing', (2011) 7, Law Env't \& Dev. J., 52-65.

J. Rana, Benefit Sharing of genetic resources convention on biodivesity, the bonn guidelines and emerging ABS framework, briefing paper 1, Research project on protection of indeginous knowledge of biodiversity, 2004.

$\mathrm{K}$. Jung $\mathrm{Ni}$, 'The incorporation of the CBD mandate on access and benefit sharing into trips regime: an appraisal of the appeal of developing countries with rich genetic resource', (2006) 1, Asian J. WTO \& Int'l Health L \& Pol'y, 433464.

K. Venkataraman, 'Access and benefit sharing and the Biological Diveristy Act of India: a progress report', (2008) 10(3), Asian Biotechnology and Development Review, 69-80.

Lulu Agustina, Tim Penyusunan Draf Akademik Rancangan Undangundang Pengelolaan Sumber Daya Genetika, Kementerian Lingkungan Hidup, Jakarta, wawancara 12 Desember 2012.

Miranda Risang Ayu, Tim Penyusun Draf Akademik Rancangan Undang-Undang Pengelolaan Sumber Daya Genetika, Jakarta, wawancara 6 November 2013. 
M. I. Jeffery, 'Bioprospecting: access to genetic resources and benefit sharing under the CBD and the Bonn Guidelines', (2002) 6, Singapore Journal International and Comparative Law, 747-808.

M. Tvedt \& T. Young, 'Beyond Access: Exploring Implementation of the Fair and Equitable Sharing Commitment in the CBD', (2007) 67(2) IUCN-Environmental Policy and Law Paper.

P. Atmosudirdjo, 1981, Hukum Administrasi Negara, Ghalia Indonesia, Jakarta.

P. M. Hadjon, 2005, Pengantar Hukum Administrasi Indonesia, Gadjah Mada University Press, Yogyakarta.

S. F. Marbun \& M. Mahfud M.D, 2006, Pokok-Pokok Hukum Administrasi Negara, Liberty, Yogyakarta. 